\title{
Phylogenetic Relationship of Gemella morbillorum to Gemella haemolysans
}

\author{
ANNE M. WHITNEY* AND STEVEN P. O'CONNOR \\ Respiratory Diseases Branch, Division of Bacterial and Mycotic Diseases, National Center for Infectious \\ Diseases, Centers for Disease Control and Prevention, Atlanta, Georgia 30333
}

\begin{abstract}
Partial 16S rRNA gene sequences (16S rDNA) of Gemella morbillorum and Gemella haemolysans were determined by sequencing polymerase chain reaction-amplified DNA. A phylogenetic analysis of 53 eubacterial 16S rRNA sequences grouped the gemellae on a distinct branch separate from the 18 members of the genus Streptococcus. DNA-DNA hybridization results indicate that the two gemellae are related at the genus level but are not a single species.
\end{abstract}

Gemella haemolysans, the original member of the genus Gemella, was first described in 1938 as Neisseria haemolysans by Thjötta and Böe (38). Several studies showed that $N$. haemolysans was biochemically quite different from other Neisseria species (for a review, see reference 8), and Berger proposed the new genus Gemella (7).

Gemella morbillorum was originally isolated in 1917 by Tunnicliff from the blood of 42 patients during the early stages of measles (40). She later named the gram-positive organism Diplococcus rubeolae (41). Prevot also isolated an organism from patients with measles and named it Diplococcus morbillorum (33). The two Diplococcus species were apparently identical, and Tunnicliff adopted the name $D$. morbillorum. Although $D$. morbillorum could be grown under aerobic conditions after several transfers, it was primarily anaerobic and was transferred to the genus Peptostreptococcus by Smith (36). Peptostreptococcus morbillorum, however, was found to have lactic acid as its major by-product of metabolism, and Holdeman and Moore (26) transferred it to the genus Streptococcus.

The 16S rRNA oligonucleotide catalog of Streptococcus morbillorum closely resembled that of $G$. haemolysans (31), and in 1988, Kilpper-Bälz and Schleifer's DNA-DNA filter hybridization results and $\mathrm{G}+\mathrm{C}$ content analysis compelled them to propose that $S$. morbillorum be transferred to the genus Gemella as $G$. morbillorum comb. nov. (30). The G+C content of $S$. morbillorum was $30 \mathrm{~mol} \%$, compared with 33 mol\% for $G$. haemolysans and 38 to $46 \mathrm{~mol} \%$ for strepto$\operatorname{cocci}(31)$.

$G$. morbillorum and $G$. haemolysans were found to be morphologically and physiologically very similar, and Facklam and Wilkinson concluded that the two species were actually identical (23). Later studies, however, demonstrated that $G$. haemolysans could be differentiated from $G$. morbillorum by biochemical assays including nitrite reduction (see references 8 and 9). Both species are considered commensal with humans, but each has been implicated as a causative agent of endocarditis $(5,13,29,32)$. $G$. haemolysans has been reported in clinical cases of septicemia and meningitis and an infection of a total knee arthroplasty $(21,22)$.

We sought to further define the phylogenetic relationship of $G$. morbillorum to $G$. haemolysans by determining and comparing the sequences of the 16S rRNA gene (16S rDNA) from the type strains of both species. The two 16S rRNA

\footnotetext{
* Corresponding author.
}

gene sequences were then aligned with 16S rRNA (rDNA) sequences of 51 eubacterial species representing 11 genera, and a phylogenetic tree was constructed. The tree and DNA-DNA hybridization results confirm the separation of the genera Gemella and Streptococcus and show that $G$. haemolysans and $G$. morbillonum are unique species.

\section{MATERIALS AND METHODS}

Bacteria. Bacterial cultures used in this study were $G$. morbillorum ATCC $27824^{\mathrm{T}}$, G. haemolysans ATCC $10379^{\mathrm{T}}$, and Aerococcus viridans ATCC $11563^{\mathrm{T}}$.

Preparation of genomic DNA for PCR or hybridization. $G$. morbillorum was grown for $24 \mathrm{~h}$ at $37^{\circ} \mathrm{C}$ on Trypticase soy agar supplemented with 5\% sheep blood (BBL Microbiology Systems, Cockeysville, Md.). Cells were harvested by scraping with an inoculating loop and were suspended in 500 $\mu l$ of $0.2 \mathrm{M}$ sodium acetate. The bacteria were washed once with $0.2 \mathrm{M}$ sodium acetate and suspended in $500 \mu \mathrm{l}$ of TE (10 $\mathrm{mM}$ Tris-HCl [pH 8.0], $1 \mathrm{mM}$ EDTA). Ten microliters of mutanolysin (Sigma Chemical Co., St. Louis, Mo.) $(1 \mathrm{mg} / \mathrm{ml})$ was added to the resuspended bacteria, and the tube was incubated at $37^{\circ} \mathrm{C}$ for $1 \mathrm{~h}$. The suspension was then transferred to a thermal cycler and heated at $100^{\circ} \mathrm{C}$ for $10 \mathrm{~min}$. Cellular debris was pelleted by centrifugation, and $10 \mu \mathrm{l}$ of the resulting supernatant was used in each $100-\mu l$ polymerase chain reaction (PCR).

Chromosomal DNA for DNA-DNA hybridization was prepared from each strain by growing 1 liter of culture in Todd-Hewitt broth supplemented with yeast extract (Difco Laboratories, Detroit, Mich.) at $37^{\circ} \mathrm{C}$ overnight. The bacteria were washed in SSC $(1 \times \mathrm{SSC}$ is $0.15 \mathrm{M} \mathrm{NaCl}$ plus 0.015 $M$ sodium citrate) and suspended in $20 \mathrm{ml}$ of SSC. An equal volume of glass beads was added to the suspension, and the bacteria were disrupted in a Braun homogenizer (B. Braun Biotech International, Allentown, Pa.) for $2 \mathrm{~min}$. After the beads were allowed to settle, the supernatant was recovered, extracted once with phenol and twice with $\mathrm{CHCl}_{3}$, and precipitated with ethanol overnight. The DNA was washed with unlabeled $70 \%$ ethanol and suspended in $900 \mu \mathrm{l}$ of $\mathrm{H}_{2} \mathrm{O}$. One hundred microliters of $10 \times$ STE $(1 \times$ STE is $100 \mathrm{mM}$ $\mathrm{NaCl}, 10 \mathrm{mM}$ Tris, and $1 \mathrm{mM}$ EDTA [pH 7.4]) was added to the DNA suspension. RNase (Sigma) was added to a final concentration of $50 \mu \mathrm{g} / \mathrm{ml}$, and the suspension was heated at $60^{\circ} \mathrm{C}$ for $1 \mathrm{~h}$. Pronase (Sigma) was then added to a final concentration of $50 \mu \mathrm{g} / \mathrm{ml}$, and the suspension was heated at $37^{\circ} \mathrm{C}$ for $1 \mathrm{~h}$. The DNA was extracted as described above and resuspended in $\mathrm{H}_{2} \mathrm{O}$. The optical density at $260 \mathrm{~nm}$ of the 
DNA suspension was determined, and the concentration of the DNA was adjusted to $1 \mathrm{mg} / \mathrm{ml}$.

Template preparation and sequencing. Primers fD1 $\left(5^{\prime}-\right.$ agagtttgatcctggctcag) and rD1 (5'-aaggaggtgatccagcc) (44) were used to amplify the $16 \mathrm{~S}$ rDNA as previously described (19). Each $100-\mu 1$ reaction mixture contained $10 \mu \mathrm{l}$ of supernatant from the $G$. morbillorum bacterial cell lysate or $10 \mu \mathrm{l}$ of $G$. haemolysans DNA diluted to $1 \mu \mathrm{g} / \mathrm{ml}$. Ten reaction mixtures were pooled, and $10 \mu \mathrm{l}$ of the pool was run on a $1 \%$ agarose gel to check concentration and purity. Purification of the PCR product with streptavidin-coated magnetic beads (Dynabeads M-280; Dynal, Inc. Great Neck, N.Y.) has been described elsewhere (19).

Sequenase version 2.0 (U.S. Biochemicals, Cleveland, Ohio) was used to sequence each strand of the PCR product by the dideoxy chain termination method described by Sanger et al. (35). ${ }^{35} \mathrm{~S}$-dATP was purchased from New England Nuclear (Dupont Corporation, Wilmington, Del.). The standard protocols were followed with $7 \mu \mathrm{l}$ of beads or supernatant containing template DNA in each reaction. Ten of the primers used for sequencing were derived from Stackebrandt and Charfreitag (37). Primer 235 (5'-GCACCG CAAAGCCATCTC) was derived from the $G$, haemolysans 16S rDNA sequence as it became known (the present study).

Phylogenetic analysis. Partial 16S rDNA consensus sequences for $G$. haemolysans and $G$. morbillorum were determined after results from three or more Sequenase reactions from each strand of DNA template were aligned and edited by using the DNASTAR (Madison, Wis.) software package. The two sequences, representing approximately $98 \%$ of their respective genes, were then aligned with 51 other eubacterial 16S rDNA sequences or 16S rRNA sequences representing 11 genera by the Pileup program in the Genetics Computer Group sequence analysis package (20). The accession numbers, strain designations, and references for the sequences used in the alignment are listed in Table 1 . The alignment was edited by removing approximately 150 nucleotides at the $5^{\prime}$ end of the sequences including the V1 region (nomenclature of Gray et al. [25]) and by removing the $3^{\prime}$ terminus including the V5 region. The resulting length of 1,350 nucleotides corresponded to bases 149 through 1477 in the Escherichia coli nomenclature described by Brosius et al. (12). Phylogenetic analyses were based on a distance matrix output generated by the PHYLIP version 3.4 DNADIST program (24) using the nucleotide substitution model described by Jukes and Cantor (28). The neighbor-joining method described by Saitou and Nei (34) was used to generate unrooted trees assuming no evolutionary clock. The distance matrix input was taken in random order. The outgroup for this analysis was Anacystis nidulans 16S rDNA (39). A rooted phenogram was then constructed (Drawgram; PHYLIP version 3.4).

DNA-DNA hybridization. Sonicated genomic DNAs from $G$. morbillorum, $G$. haemolysans, and $A$. viridans were used in DNA-DNA hybridization assays in a modification of the methods described by Brenner et al. (11). One microgram of $G$. haemolysans DNA was labeled with $\left[{ }^{35} \mathrm{P}\right] \mathrm{dCTP}$ in a nick translation system (GIBCO-BRL, Gaithersburg, Md.). Unincorporated label was removed by passing the reaction through a nick column (Sephadex G-50; Pharmacia, Piscataway, N.J.). Labeled $G$. haemolysans DNA was then diluted to $0.33 \mu \mathrm{g} / \mathrm{ml}$ (specific activity was $4 \times 10^{5}$ to $2.4 \times 10^{6}$ $\mathrm{cpm} / \mu \mathrm{g}$ ) in $0.28 \mathrm{M}$ phosphate buffer containing $150 \mu \mathrm{g}$ of unlabeled homologous or heterologous DNA per ml. A negative control tube contained only labeled $G$. haemolysans DNA in $0.28 \mathrm{M}$ phosphate buffer. Hybridization
TABLE 1. Sources and accession numbers of 16S rRNA (rDNA) sequences used in this study

\begin{tabular}{|c|c|c|c|}
\hline Organism & Strain & $\begin{array}{c}\text { Accession } \\
\text { no. }\end{array}$ & $\begin{array}{c}\text { Reference } \\
\text { or } \\
\text { source }^{a}\end{array}$ \\
\hline erococcus urinae & NCFB $2893^{\mathrm{T}}$ & M77819 & 2 \\
\hline Aerococcus viridans & ATCC $11563^{\mathrm{T}}$ & M58797 & NP \\
\hline Alloiococcus otitis & NCFB 2890 & X59765 & 1 \\
\hline Anacystis nidulans & & $\mathrm{X} 03538$ & 39 \\
\hline Bacillus anthracis & Sterne & X55059 & 3 \\
\hline Bacillus cereus & NCDO $1771^{T}$ & X55060 & 3 \\
\hline Bacillus subtilis & NCDO 1769 & X60646 & 4 \\
\hline Brochothrix campestris & ATCC $43754^{\mathrm{T}}$ & X56156 & 17 \\
\hline Brochothrix thermosphacta & NCDO $1676^{\mathrm{T}}$ & X56155 & 17 \\
\hline Carnobacterium divergens & NCDO $2763^{\mathrm{T}}$ & X54270 & 42 \\
\hline Carnobacterium gallinarum & NCFB $2766^{\mathrm{T}}$ & X54269 & 42 \\
\hline Carnobacterium mobile & NCFB $2765^{\mathrm{T}}$ & X54271 & 42 \\
\hline Carnobacterium piscicola & NCDO $2762^{\mathrm{T}}$ & $\times 54268$ & 42 \\
\hline Enterococcus faecium & NCDO $942^{\mathrm{T}}$ & & 46 \\
\hline Enterococcus hirae & $\mathrm{NCDO} 1258^{\mathrm{T}}$ & & 46 \\
\hline Gemella haemolysans & & M58799 & NP \\
\hline Gemella haemolysans & ATCC $10379^{\mathrm{T}}$ & L14326 & TS \\
\hline Gemella morbillorum & ATCC $27824^{\mathrm{T}}$ & L14327 & TS \\
\hline Helcococcus kunzii & NCFB $2900^{\mathrm{T}}$ & & 15 \\
\hline Lactobacillus acidophilus & NCDO $1748^{\mathrm{T}}$ & X61138 & 16 \\
\hline Lactobacillus delbrueckii & DSM $20074^{\mathrm{T}}$ & M58814 & NP \\
\hline Lactococcus garvieae & NCDO $2155^{\mathrm{T}}$ & $\mathrm{X} 54262$ & 14 \\
\hline Lactococcus piscium & NCFB $2778^{\mathrm{T}}$ & X53905 & 47 \\
\hline Lactococcus plantarum & NCDO $1869^{\mathrm{T}}$ & X54259 & 14 \\
\hline ccus raffinolactis & NCDO $617^{\mathrm{T}}$ & X54261 & 14 \\
\hline Lactococcus lactis & NCDO $2118^{\mathrm{T}}$ & X54260 & 14 \\
\hline Leuconostoc mesenteroides & DSM $20343^{\mathrm{T}}$ & M23035 & 49 \\
\hline $\begin{array}{l}\text { Leuconostoc } \\
\quad \text { paramesenteroides }\end{array}$ & DSM $20288^{\mathrm{T}}$ & M23033 & 49 \\
\hline Listeria innocua & NCTC $11288^{\mathrm{T}}$ & X56152 & 17 \\
\hline Listeria monocytogenes & ATCC 35152 & M58822 & 17 \\
\hline Pediococcus damnosus & NCDO $1832^{\mathrm{T}}$ & & 18 \\
\hline Pediococcus parvulus & NCDO $1634^{\mathrm{T}}$ & & 18 \\
\hline Pediococcus pentosaceus & DSM 20336 & M58834 & NP \\
\hline Streptococcus acidominimus & NCDO $2025^{\mathrm{T}}$ & X58301 & 6 \\
\hline Streptococcus alactolyticus & NCDO $1091^{\mathrm{T}}$ & X58319 & 6 \\
\hline Streptococcus anginosus & NCTC $10713^{\mathrm{T}}$ & X58309 & 6 \\
\hline Streptococcus bovis & NCDO $597^{\mathrm{T}}$ & X58317 & 6 \\
\hline Streptococcus cricetus & NCDO $2720^{\mathrm{T}}$ & X58305 & 6 \\
\hline Streptococcus equi & NCDO $2493^{\mathrm{T}}$ & X58314 & 6 \\
\hline Streptococcus equinus & NCDO $1037^{\mathrm{T}}$ & X58318 & 6 \\
\hline Streptococcus hyointestinalis & DSM $20770^{\mathrm{T}}$ & X58313 & 6 \\
\hline Streptococcus iniae & NCDO $2772^{\mathrm{T}}$ & X58316 & 6 \\
\hline Streptococcus intermedius & NCTC $11324^{\mathrm{T}}$ & X58311 & 6 \\
\hline Streptococcus mutans & NCTC $10499^{\mathrm{T}}$ & X58303 & 6 \\
\hline Streptococcus parasanguis & ATCC $15912^{\mathrm{T}}$ & X53652 & 45 \\
\hline Streptococcus pneumoniae & NCTC $7465^{\mathrm{T}}$ & $\mathrm{X} 58312$ & 6 \\
\hline Streptococcus pyogenes & NCDO $2381^{\mathbf{T}}$ & $\times 59029$ & 6 \\
\hline Streptococcus rattus & NCDO $2723^{T}$ & X58304 & 6 \\
\hline Streptococcus salivarius & ATCC 13419 & M58839 & NP \\
\hline Streptococcus sanguis & NCTC $7863^{T}$ & X53653 & 45 \\
\hline Streptococcus sobrinus & DSM $20742^{\mathrm{T}}$ & X58307 & 6 \\
\hline Tetragenococcus halophilus & NCBI $12011^{\mathrm{T}}$ & & 18 \\
\hline Vagococcus fluvialis & NCDO $2497^{\mathrm{T}}$ & X54258 & 14 \\
\hline Vagococcus salmoninarum & NCFB $27777^{\mathrm{T}}$ & X54272 & 42 \\
\hline
\end{tabular}

${ }^{a}$ TS, this study; NP, submitted to GenBank as unpublished.

was carried out at $55^{\circ} \mathrm{C}$ (optimal) or $70^{\circ} \mathrm{C}$ (stringent). The $55^{\circ} \mathrm{C}$ reaction conditions are such that the DNA reaches 100 $C_{0} t \mathrm{~s}$ by $16 \mathrm{~h}$. After renaturation, the single-stranded DNA was separated from the double-stranded DNA by passing the samples through a hydroxylapatite column. The hydroxylapatite-bound DNA was eluted by sequentially increasing the wash temperature by $5^{\circ} \mathrm{C}$. 


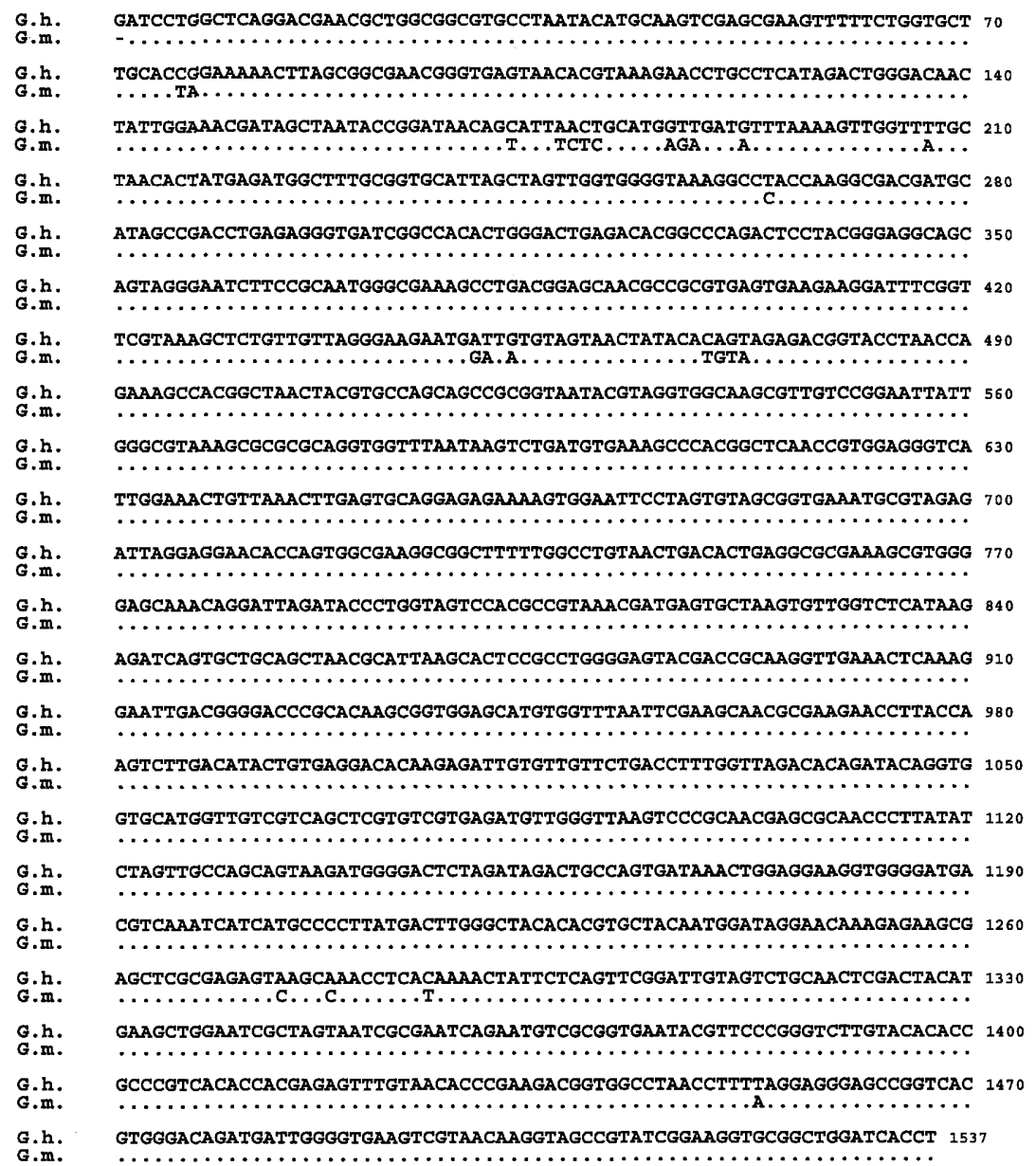

FIG. 1. Aligned 16S rRNA sequences from G. haemolysans (G.h.) and G. morbillorum (G.m.). Consensus nucleotides are indicated by periods.

The thermal elution midpoint, the temperature at which $50 \%$ of the double-stranded DNA had melted and was eluted from the hydroxylapatite bed, was determined for the homologous and heterologous hybridization reactions. Compared with the homologous reaction, a decrease in the thermal elution midpoint of a heterologous reaction by $1^{\circ} \mathrm{C}$ is indicative of approximately $1 \%$ mismatched base pairs (10), i.e., $1 \%$ divergence.

DNA relatedness between $G$. haemolysans and $A$. viridans or $G$. morbillorum was determined by assaying the percentage of double-stranded DNA in the total DNA of each reaction (binding ratio), subtracting the nonassociated labeled DNA, and relating the heterologous difference to the homologous difference (relative binding ratio). The relative binding ratios for the 55 and the $70^{\circ} \mathrm{C}$ reaction mixtures were determined.

Nucleotide sequence accession numbers. The 16S rDNA sequences were deposited in GenBank under the accession numbers L14327 (G. morbillorum) and L14326 (G. haemolysans).

\section{RESULTS AND DISCUSSION}

PCR amplification of the 16S rRNA gene (16S rDNA) from $G$. haemolysans or $G$. morbillorum generated a single product for each organism that migrated at approximately 1,500 bp. The PCR products were sequenced, and the two sequences were aligned. The alignment (Fig. 1) showed 24 differences over the 1,536-base length, giving a similarity value of $98.44 \%$. Twenty-three of the 24 nucleotide differences were in typically variable regions of the rRNA sequence (11). Variable region 1 (V1) contained 2 bases that were not homologous; totals of $10,7,3$, and 1 bases were located in V2, in V6, in V9, and in V5, respectively. Both sequences exhibited all 40 of the specific nucleotides of the $16 \mathrm{~S}$ rRNA signature characteristic of the gram-positive eubacteria with a low $\mathrm{G}+\mathrm{C}$ content (48).

TABLE 2. DNA relatedness between $G$. haemolysans and $G$. morbillorum or $A$. viridans

\begin{tabular}{|c|c|c|c|}
\hline \multirow[t]{2}{*}{$\begin{array}{c}\text { Source of } \\
\text { unlabeled DNA }\end{array}$} & \multicolumn{2}{|c|}{$\begin{array}{c}\% \text { Relatedness } \\
\text { to labeled } \\
\text { DNA from } \\
\text { G. haemolysans } \\
\text { type strain } \\
\text { ATCC } 10379\end{array}$} & \multirow[t]{2}{*}{$\begin{array}{c}\% \\
\text { Divergence }\end{array}$} \\
\hline & $55^{\circ} \mathrm{C}$ & $70^{\circ} \mathrm{C}$ & \\
\hline G. haemolysans ATCC $10379^{\mathrm{T}}$ & 100.0 & 100.0 & 0.0 \\
\hline G. morbillorum ATCC $27824^{\mathrm{T}}$ & 21.5 & 10.5 & 10.7 \\
\hline A. viridans ATCC $11563^{\mathrm{T}}$ & 4.2 & 3.5 & 11.9 \\
\hline
\end{tabular}




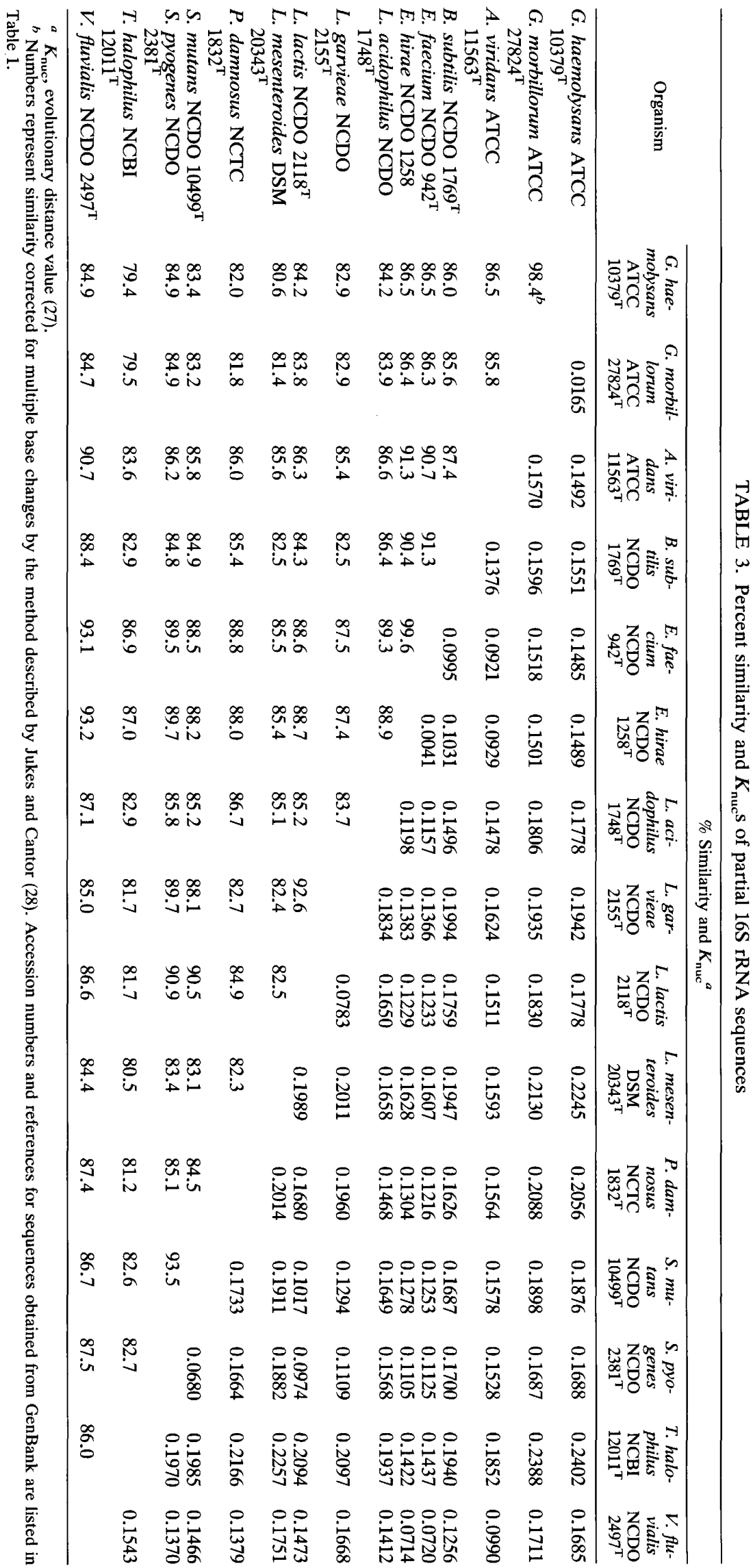




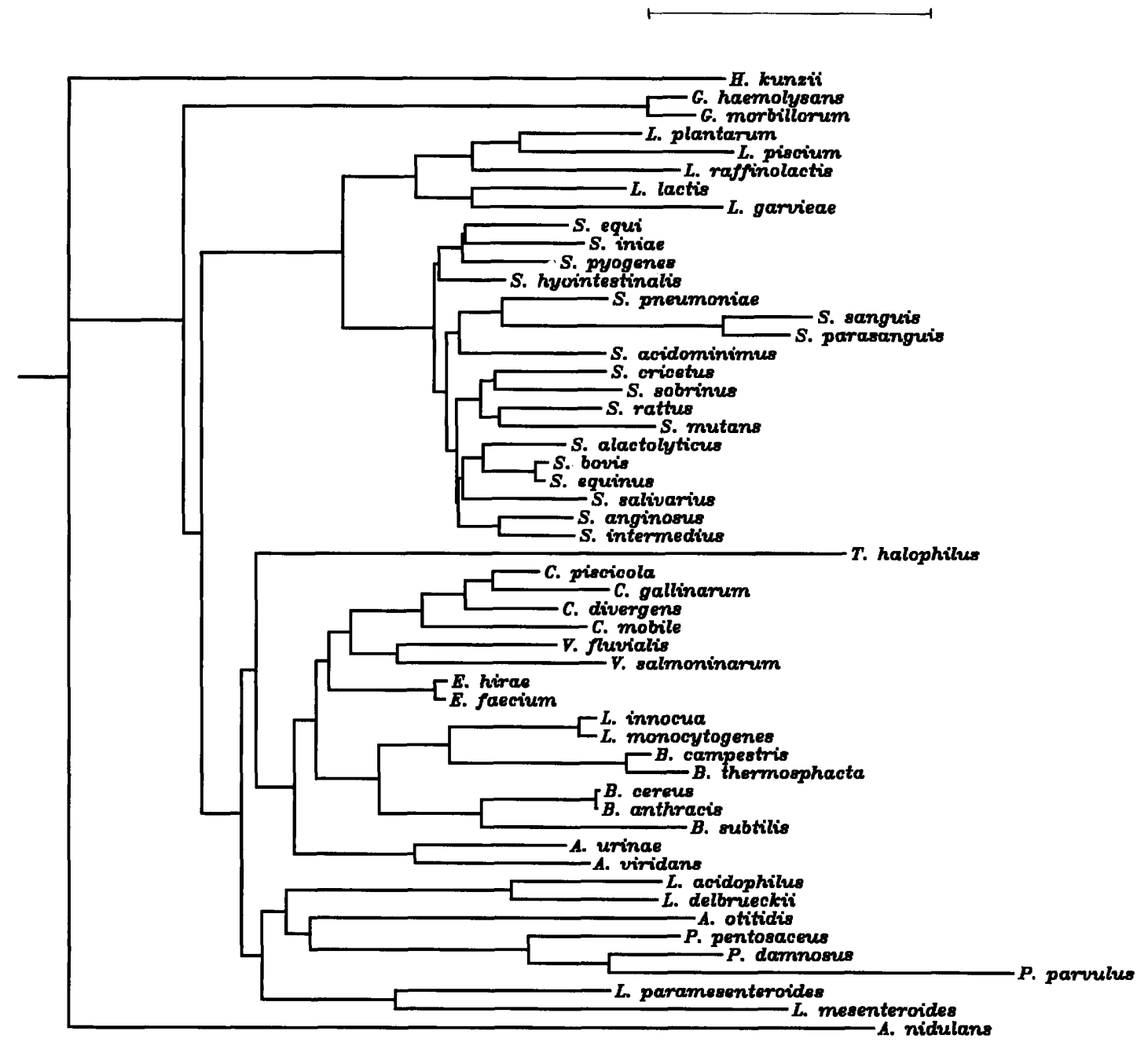

FIG. 2. Phylogenetic tree based on 16S rDNA sequences using the neighbor-joining method described by Saitou and Nei (34). The bar represents $5 \%$ difference in nucleotide sequence.

The G. haemolysans $16 \mathrm{~S}$ rDNA sequence was also aligned with the $G$. haemolysans $16 \mathrm{~S}$ rRNA sequence retrieved from GenBank (Table 1) that had been determined by reverse transcriptase (data not shown). We were able to identify 60 bases that were ambiguous in the rRNA sequence; we found 1 base that differed and needed to introduce a 1-base gap at position 1487 to accommodate a guanosine in the rRNA sequence that we were unable to confirm.

DNA-DNA hybridization assay results between the total genomic DNAs of $G$. haemolysans and $G$. morbillorum are shown in Table 2. According to Wayne et al., a species is defined phylogenetically by "approximately $70 \%$ or greater DNA-DNA relatedness and with $5^{\circ} \mathrm{C}$ or less $\Delta T_{m}$ "(43). At optimal conditions, $G$. haemolysans and $G$. morbillorum showed only $21.5 \%$ DNA-DNA relatedness and a $\Delta T_{m}$ of $10.7^{\circ} \mathrm{C}$. These results indicate that $G$. haemolysans and $G$. morbillorum are related at the genus level but not at the species level.

The sequences of the 16S rRNA genes from $G$. haemolysans and G. morbillonum were aligned with 51 other eubacterial 16S rRNA (rDNA) sequences retrieved from EMBL or GenBank. Before analysis of the data for homology, the $5^{\prime}$ end of the alignment (nucleotides 1 to 148 [E. coli nomenclature]) including the hypervariable $\mathrm{V} 1$ region was removed during editing, the region from nucleotide 1478 to the $3^{\prime}$ terminus including variable region V5 was also deleted, and small changes were made manually when it was evident that the gaps were misplaced. No other variable regions over the 1,350-nucleotide length were removed. Distance and homology matrices were generated, and representative values are shown in Table 3 . A phylogenetic tree was drawn by the neighbor-joining method with $A$. nidulans as the outgroup to root the tree (Fig. 2).

The 16S rRNA sequences from $G$. haemolysans and $G$. morbillorum showed high sequence similarity (98.4\%), and the gemellae formed a phylogenetically distinct branch in the tree separate from the streptococcal cluster. The enterococcus sequences showed the highest degree (ca. $86.4 \%$ ) of homology with the sequences of the gemellae, and Pediococcus parvulus demonstrated the least degree $(77.5 \%)$. The 18 streptococcal 16S rRNA sequences were 83.5 to $85.6 \%$ homologous with the Gemella sequences, while the sequences within the streptococcal group showed 93.0 to 99.6\% homology with each other. In the sequence alignment, the streptococcal sequences also showed a unique pattern at position 234 (CT), position 845 (GGG), and position 1264 
(CG) (E. coli nomenclature). The other sequences, including those of G. morbillorum and G. haemolysans, do not contain these nucleotide patterns. G. haemolysans and G. morbillorum possess an exclusive signature at positions 667 and 709; an adenine replaced an otherwise conserved guanine and a thymine (uracil), respectively. These sequence signatures may be useful in designing genus-specific probes.

We have shown through 16S rDNA sequence comparisons and DNA-DNA hybridizations that $G$. haemolysans and $G$. morbillorum are separate species in the genus Gemella and that the gemellae are phylogenetically distinct from the streptococci and other gram-positive bacteria with low $\mathrm{G}+\mathrm{C}$ contents. The phylogenetic tree presented here was based on a continuous region of 1,350 nucleotides of the 16S rDNA sequence. Other trees constructed from alignments in which one or more internal variable regions were removed changed the branching order and some branch lengths but did not alter the placement of the gemellae on a distinct branch (data not shown). In addition, in every tree configuration, organisms formed tight clusters according to genus, in agreement with previous taxonomic classification.

\section{REFERENCES}

1. Aguirre, M., and M. D. Collins. 1991. Phylogenetic analysis of Alloiococcus otitis gen. nov. sp. nov., an organism from human middle ear fluid. Int. J. Syst. Bacteriol. 42:79-83.

2. Aguirre, M., and M. D. Collins. 1992. Phylogenetic analysis of some Aerococcus-like organisms from urinary tract infections: description of Aerococcus urinae sp. nov. J. Gen. Microbiol. 138:401-405.

3. Ash, C., J. A. E. Farrow, M. Dorsch, E. Stackebrandt, and M. D. Collins. 1991. Comparative analysis of Bacillus anthracis, Bacillus cereus, and related species on the basis of reverse transcriptase sequencing of $16 \mathrm{~S}$ rRNA. Int. J. Syst. Bacteriol. 41:343-346.

4. Ash, C., J. A. E. Farrow, S. Wallbanks, and M. D. Collins. 1991. Phylogenetic heterogeneity of the genus Bacillus revealed by comparative analysis of small-subunit-ribosomal RNA sequences. Lett. Appl. Microbiol. 13:202-206.

5. Bell, E., and A. C. McCartney. 1992. Gemella morbillorum endocarditis in an intravenous drug abuser [letter]. J. Infect. 25:110-112.

6. Bentley, R. W., J. A. Leigh, and M. D. Collins. 1991. Intrageneric structure of Streptococcus based on comparative analysis of small-subunit rRNA sequences. Int. J. Syst. Bacteriol. 41: $487-494$.

7. Berger, U. 1961. A proposed new genus of Gram-negative cocci: Gemella. Int. Bull. Bacteriol. Nomencl. Taxon. 11:17-19.

8. Berger, U. 1992. The genus Gemella, p. 1643-1653. In A. Balows, H. G. Truper, M. Dworkin, W. Harder, and K.-H. Schliefer (ed.), The prokaryotes, 2nd ed. Springer-Verlag, New York.

9. Berger, U., and A. Pervanidis. 1986. Differentiation of Gemella haemolysans (Thjötta and Böe 1938) Berger 1960, from Streptococcus morbillorum (Prevot 1933) Holdeman and Moore 1974. Zentralbl. Bakteriol. Hyg. A 261:311-321.

10. Bonner, T. I., D. J. Brenner, B. R. Neufeld, and R. J. Britten. 1973. Reduction in the rate of DNA reassociation by sequence divergence. J. Mol. Biol. 81:123-135.

11. Brenner, D. J., A. C. McWhorter, J. K. L. Knutson, and A. G. Steigerwalt. 1982. Escherichia vulneris: a new species of Enterobacteriaceae associated with human wounds. J. Clin. Microbiol. 15:1133-1140.

12. Brosius, J., M. L. Palmer, P. J. Kennedy, and H. F. Noller. 1978. Complete nucleotide sequence of a 16S ribosomal RNA gene from Escherichia coli. Proc. Natl. Acad. Sci. USA 75:48014805.

13. Buu-Hoi, A., A. Sapoetra, C. Branger, and J. F. Acar. 1982. Antimicrobial susceptibility of Gemella haemolysans isolated from patients with subacute endocarditis. Eur. J. Clin. Microbiol. 1:102-106.
14. Collins, M. D., C. Ash, J. A. E. Farrow, S. Wallbanks, and A. M. Williams. 1989. 16S ribosomal ribonucleic acid sequence analyses of lactococci and related taxa. Description of Vagococcus fluvialis gen. nov., sp. nov. J. Appl. Bacteriol. 67:453460.

15. Collins, M. D., R. R. Facklam, U. M. Rodrigues, and K. L. Ruoff. 1993. Phylogenetic analysis of some Aerococcus-like organisms from clinical sources: description of Helcococcus kunzii gen. nov., sp. nov. Int. J. Syst. Bacteriol. 43:425-429.

16. Collins, M. D., U. Rodrigues, C. Ash, M. Aguirre, J. A. E. Farrow, A. Martinez-Murcia, B. A. Philips, A. M. Williams, and S. Wallbanks. 1991. Phylogenetic analysis of the genus Lactobacillus and related lactic acid bacteria as determined by reverse transcriptase sequencing of $16 S$ rRNA. FEMS Microbiol. Lett. 77:5-12.

17. Collins, M. D., S. Wallbanks, D. J. Lane, J. Shah, R. Nietupski, J. Smida, M. Dorsch, and E. Stackebrandt. 1991. Phylogenetic analysis of the genus Listeria based on reverse transcriptase sequencing of 16S rRNA. Int. J. Syst. Bacteriol. 41:240-246.

18. Collins, M. D., A. M. Williams, and S. Wallbanks. 1990. The phylogeny of Aerococcus and Pediococcus as determined by 16S rRNA sequence analysis: description of Tetragenococcus gen. nov. FEMS Microbiol. Lett. 70:255-262.

19. Daly, J. S., M. G. Worthington, D. J. Brenner, C. W. Moss, D. G. Hollis, R. S. Weyant, A. G. Steigerwalt, R. E. Weaver, M. I. Daneshvar, and S. P. O'Connor. 1993. Rochalimaea elizabethae sp. nov. isolated from a patient with endocarditis. J. Clin. Microbiol. 31:872-881.

20. Devereux, J., P. Haeberli, and O. Smithies. 1984. A comprehensive set of sequence analysis programs for the VAX. Nucleic Acids Res. 12:387-395.

21. Eggelmeier, F., P. Petit, and B. A. C. Dijkmans. 1992. Total knee arthroplasty infection due to Gemella haemolysans. Br. J. Rheumatol. 31:67-69.

22. Facklam, R. R. 1977. Physiological differentiation of viridans streptococci. J. Clin. Microbiol. 5:184-201.

23. Facklam, R. R., and H. W. Wilkinson. 1981. The family Streptococcaceae (medical aspects), p. 1572-1597. In M. P. Starr, H. Stolp, H. G. Trüper, A. Balows, and H. G. Schlegel (ed.), The prokaryotes. Springer-Verlag, Berlin.

24. Felsenstein, J. 1991. PHYLIP-phylogeny inference package version 3.4. University of Washington, Seattle.

25. Gray, M. W., D. Sankoff, and R. J. Cedergren. 1984. On the evolutionary descent of organisms and organelles: a global phylogeny based on a highly conserved structural core in a small subunit ribosomal RNA. Nucleic Acids Res. 12:5837-5852.

26. Holdeman, L. V., and W. E. C. Moore. 1974. New genus, Coprococcus, twelve new species, and emended description of four previously described species from human feces. Int. J. Syst. Bacteriol. 24:260-277.

27. Hori, H., and S. Osawa. 1975. Evolutionary changes in $5 S$ ribosomal RNA species and phylogenetic tree of 54 5S rRNA species. Proc. Natl. Acad. Sci. USA 76:381-385.

28. Jukes, T. H., and C. R. Cantor. 1969. Evolution of protein molecules, p. 21-132. In H. N. Munro (ed), Mammalian protein metabolism, vol. 3. Academic Press, Inc., New York.

29. Kaufhold, A., D. Franzen, and R. Lütticken. 1989. Endocarditis caused by Gemella haemolysans. Infection 17:385-387.

30. Kilpper-Bälz, R., and K.-H. Schleifer. 1988. Transfer of Streptococcus morbillorum to the genus Gemella as Gemella morbillorum comb. nov. Int. J. Syst. Bacteriol. 38:442-443.

31. Ludwig, W., M. Weizenegger, R. Kilpper-Bälz, and K.-H. Schleifer. 1988. Phylogenetic relationships of anaerobic streptococci. Int. J. Syst. Bacteriol. 38:15-18.

32. Maxwell, S. 1989. Endocarditis due to Streptococcus morbillorum. J. Infect. 18:67-72.

33. Prevot, A. R. 1933. Etudes de stematique bacterienne. I. Louis generals. II. Cocci anaerobies. Ann. Soc. Nat. Zool. Biol. Anim. 15:23-260.

34. Saitou, N., and M. Nei. 1987. The neighbor-joining method: a new method for reconstructing phylogenetic trees. Mol. Biol. Evol. 4:406-425.

35. Sanger, F., S. Nicklen, and A. R. Coulson. 1977. DNA sequenc- 
ing with chain-terminating inhibitors. Proc. Natl. Acad. Sci. USA 74:5463-5467.

36. Smith, L. DS. 1957. Peptostreptococcus Kluyver and van Niel (1936), p. 533-541. In R. S. Breed, E. G. D. Murray, and N. R. Smith (ed.), Bergey's manual of determinative bacteriology, 7th ed. Williams and Wilkins, Baltimore.

37. Stackebrandt, E., and O. Charfreitag. 1990. Partial 16S rRNA primary structure of five Actinomyces species: phylogenetic implications and development of an Actinomyces israeliispecific oligonucleotide probe. J. Gen. Microbiol. 136:37-43.

38. Thjötta, T., and J. Böe. 1938. Neisseria haemolysans. A haemolytic species of Neisseria Trevisan. Acta Pathol. Microbiol. Scand. Suppl. 37:527-531.

39. Tomioka, N., and M. Sugiura. 1983. The complete nucleotide sequence of a 16S ribosomal RNA gene from a blue-green alga, Anacystis nidulans. Mol. Gen. Genet. 191:46-50.

40. Tunnicliff, R. 1917. The cultivation of a micrococcus from blood in pre-eruptive and eruptive stages of measles. JAMA 68:10281030.

41. Tunnicliff, R. 1933. Colony formation of Diplococcus rubeolae. J. Infect. Dis. 52:39-53.

42. Wallbanks, S., A. J. Martinez-Murcia, J. L. Fryer, B. A Phillips, and M. D. Collins. 1990. 16S rRNA sequence determination for members of the genus Carnobacterium and related lactic acid bacteria and description of Vagococcus salmoninarum sp. nov. Int. J. Syst. Bacteriol. 40:224-230.
43. Wayne, L. G., D. J. Brenner, R. R. Colwell, P. A. D. Grimont, O. Kandler, M. I. Krichevsky, L. H. Moore, W. E. C. Moore, R. G. E. Murray, E. Stackebrandt, M. P. Starr, and H. G. Trüper. 1987. Report of the ad hoc committee on reconciliation of approaches to bacterial systematics. Int. J. Syst. Bacteriol. 37:463-464.

44. Weisburg, W. G., S. M. Barns, D. A. Pelletier, and D. J. Lane. 1991. 16S ribosomal DNA amplification for phylogenetic study. J. Bacteriol. 173:697-703.

45. Whiley, R. A., H. Y. Fraser, C. W. I. Douglas, J. M. Hardie, A. M. Williams, and M. D. Collins. 1990. Streptococcus parasanguis sp. nov., an atypical viridans Streptococcus from human clinical specimens. FEMS Microbiol. Lett. 68:115-122.

46. Williams, A. M., U. M. Rodrigues, and M. D. Collins. 1991. Intrageneric relationships of enterococci as determined by reverse transcriptase sequencing of small-subunit rRNA. Res. Microbiol. 142:67-74.

47. Williams, A. W., J. L. Fryer, and M. D. Collins. 1990. Lactococcus piscium sp. nov., a new Lactococcus species from salmonid fish. FEMS Microbiol. Lett. 56:109-114.

48. Woese, C. R. 1987. Bacterial evolution. Microbiol. Rev. 51:221271.

49. Yang, D., and C. R. Woese. 1989. Phylogenetic structure of the 'Leuconostocs': an interesting case of a rapidly evolving organism. Syst. Appl. Microbiol. 12:145-149. 